\title{
EFEKTIVITAS METODE UMMI TERHADAP PENINGKATAN MOTIVASI BELAJAR MEMBACA ALQURAN SISWA TPA DESA PUGAAN KECAMATAN PUGAAN
}

\author{
Ahmad Rifa'i dan Muhammad Nasir \\ Dosen, STIQ Amuntai, Kalimantan Selatan
}

\begin{abstract}
Abstrak
Penelitian ini bertujuan untuk: (1) membandingkan keefektifan metode Ummi dan metode Iqra untuk meningkatkan motivasi belajar Al Qur'an Siswa TPA di Kec. Pugaan, dan (2) mengukur tingkat perubahan motivasi belajar Al Qur'an Siswa TPA di Kec. Pugaan yang menggunakan metode Ummi.

Penelitianini merupakan penelitian kuasi eksperimen dengan menggunakan angket motivasi awal dan akhir. Sampel terdiri atas dua unit kelas yaitu kelas eksperimen yang merupakan kelompok siswa yang diberikan perlakuan menggunakan metode Ummi, dan kelas kontrol yaitu kelompok siswa yang diberikan metode Iqro'. Data dikumpulkan dengan teknik observasi, angket, dan wawancara. Analisis data dengan menggunakan analisis uji-t satu pihak (independent sample t-test).

Hasil penelitian menunjukkan bahwa efektivitas peningkatan motivasi belajar membaca Alquran menunjukkan ada peningkatan signifikan antara penggunaan metode Ummi dibandingkan dengan metode konvensioanal. Pada hasil uji-t menggunakan independent sample t-test diperoleh nilai signifikansi $0,004<0,05$. Dengan demikian, pembelajaran dengan menggunakan metode Ummi efektif dalam meningkatkan motivasi belajar membaca Alquran.
\end{abstract}

Kata Kunci: Metode Ummi, Motivasi Belajar, Motivasi Belajar Membaca Alquran

\section{A. Pendahuluan}

Alquran merupakan kitab suci umat Islam dan menjadi sumber utama ajaran Islam. Menurut Hasbi Ash Shidieqy, Alquran adalah wahyu Ilahi yang diturunkan kepada Nabi Muhammad SAW, yang telah disampaikan kepada ummatnya dengan jalan mutawattir, yang dihukumkan kafir bagi orang yang 
Ahmad Rifa'i dan Muhammad Nasir: Efektivitas Metode UMMI Terhadap Peningkatan Motivasi Belajar Membaca Alquran Siswa TPA Desa Pugaan Kecamatan Pugaan

mengingkarinya. ${ }^{1}$ Ali Hasballah (dalam Hery Noer Aly) menjelaskan bahwa Alquran adalah kalam Allah SWT. yang diturunkan kepada Nabi Muhammad Saw. dalam bahasa Arab yang terang guna menjelaskan jalan hidup yang bermaslahat bagi umat manusia di dunia dan di akhirat. ${ }^{2}$

Alquran menyatakan dirinya sebagai petunjuk (hudan), hal ini dijelaskan oleh Allah dalam firman-Nya:

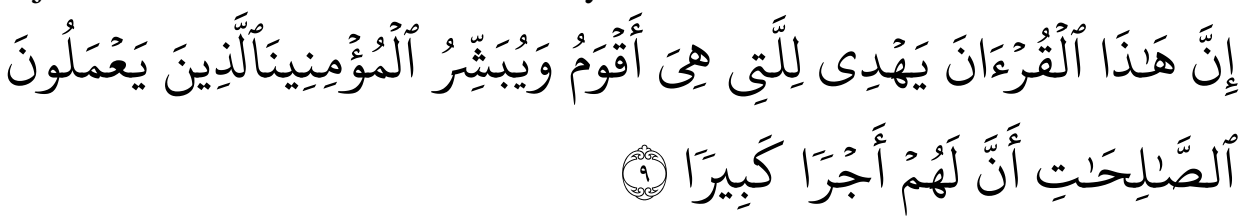

Artinya: "Sesungguhnya Al Quran ini memberikan petunjuk kepada (jalan) yang lebih Lurus dan memberi khabar gembira kepada orang-orang Mu'min yang mengerjakan amal saleh bahwa bagi mereka ada pahala yang besar." (Q.S Al-Isra ayat 9).

Ayat di atas menjelaskan bahwa Alquran diturunkan kepada Nabi Muhammad Saw. bertujuan memberikan petunjuk kepada umat manusia ke jalan kebaikan dunia akhirat. ${ }^{3}$

Alquran sumber utama ajaran Islam menjadikannya wajib untuk dipelajari dan mengajarkan jika sudah mempunyai pemahaman. Pembelajaran Alquran sebagai sesuatu kegiatan interaksi belajar mengajar juga mempunyai tujuan, yaitu: 1) agar pelajar dapat membaca Alquran dengan fasih dan betul menurut tajwid, 2) agar pelajar dapat membiasakan Alquran dalam kehidupannya, 3) memperkaya pembendaharaan kata-kata dan kalimat-kalimat yang indah dan menarik hati. ${ }^{4}$

${ }^{1}$ M. Hasbi Ash Shiddieqy, Sejarah dan Pengantar Ilmu Al-Qur'an dan Tafsir (Semarang: Pustaka Riski Putra, 1997), h. 5.

${ }^{2}$ Hery Noer Aly, Ilmu Pendidikan Islam (Jakarta: Logos, 1999), h. 32.

${ }^{3}$ Noer Aly, h. 32.

${ }^{4}$ Mahmud Yunus, Metodik Khusus Pendidikan Agama, Cet. Ke-12 (Jakarta: Hida Karya Agung, 1990), h. 91.

Jurnal Ilmiah Al QALAM, Vol. 12, No. 2, Juli-Desember 2018 
Ahmad Rifa'i dan Muhammad Nasir: Efektivitas Metode UMMI Terhadap Peningkatan Motivasi Belajar Membaca Alquran Siswa TPA Desa Pugaan Kecamatan Pugaan

Memahami Alquran menjadi tanggung jawab setiap muslim laki-laki dan perempuan melalui proses ta $^{\prime}$ lim $^{5}$ baik secara formal ataupun informal selama lembaga pendidikan tersebut mengajarkan ilmu Alquran. Sebelum mampu memhami Alquran secara mendalam baik secara arti sampai kepada penafsiran, kita harus mampu membaca Alquran tersebut. Oleh karena itu, para ulama yang lebih dulu menguasai Alquran dan mempunyai gairah untuk mengajarkan Alquran kepada generasi muslim selanjutnya, mereka membuat metode belajar membaca Alquran agar lebih mudah dipahami seperti metode IQRO', ' metode Qira'ati, metode Baghdadiyah, metode Ummi, dan masih ada beberapa metode lainnya.

Taman Pendidikan Alquran (TPA) merupakan lembaga pendidikan Islam yang mengajarkan membaca Alquran sejak usia dini, serta memahami dasar-dasar agama Islam pada anak usia taman kanak-kanak sampai usia sekolah dasar. TPA termasuk lembaga pendidikan Islam yang bersifat nonformal dan sehingga proses belajar mengajar dilakukan pada siang hari atau sore hari setelah shalat Ashar. Adapun metode yang digunakan di TPA sebagian besar masih menggunakan metode Iqro', seperti di TPA Al Ihsan dan TPA Raudhatus Sa'adah yang juga menggunakan metode Iqro', karena yang sudah familiar dikalangan masyarakat Indonesia khususnya di Kabupaten Pugaan Kecamatan Tabalong. ${ }^{7}$

Penggunaan metode Iqro' di TPA di atas mempunyai kelebihan seperti pengklasifikasian kesukaran yang diberikan perjilid (dari jilid 1 sampai 6)

${ }^{5}$ Ta'lim merupakan masdar dari kata 'allama yang berarti pengajaran, pengetahuan, dan keterampilan, atau pembelajaran yang hanya sebatas proses memberikan materi (konitif) dan seperangkat nilai (afektif) serta berupa keterampilan (psikomotorik). Lihat, Ali Mufron, Ilmu Pendidikan Islam (Yogyakarta: Aura Pustaka, 2013), h. 6.

${ }^{6}$ Metode tersebut menggunakan buku Iqra' yang disusun oleh Ustadz As ${ }^{\text {ee } a d}$ Humam sekitar tahun 1983 - 1988. Lihat, Budiyanto, HM, Prinsip-prinsip Buku Iqro' (Yogyakarta: Team tadarus AMM, t.t.).

7 Observasi di TPA Al Ihsan dan TPA Raudhatus Sa'adah Desa Pugaan, Kecamatan Pugaan, Kabupatern Tabalong, Provinsi Kalimantan Selatan, tanggal 20 Februari 2018.

Jurnal Ilmiah Al QALAM, Vol. 12, No. 2, Juli-Desember 2018 
Ahmad Rifa'i dan Muhammad Nasir: Efektivitas Metode UMMI Terhadap Peningkatan Motivasi Belajar Membaca Alquran Siswa TPA Desa Pugaan Kecamatan Pugaan

sehingga akan mempermudah dalam pengajarannya, guru memperhatikan satu persatu bacaan siswa sehingga pembelajaran dapat dilakukan secara merata kesemua siswa. Disamping itu metode ini juga mempunyai kelemahan, dari segi prosesnya guru lebih fokus kepada siswa yang mendapat giliran membaca sedangkan siswa lain kurang diperhatikan. Oleh karena itu, tidak jarang siswa melakukan hal lain (bermain, berbicara dan lain-lain) dari pada memperhatikan guru dan temannya yang kena giliran membaca di depan guru.

Menurut Purwanto (dalam Thobrani dan Arif Mustofa) menjelaskan bahwa salah satu faktor yang mempengaruhi proses belajar mengajar adalah motivasi, ${ }^{89}$ Siswa yang mempunyai motivasi rendah akan terlihat dari aktivitas dan keinginannya dalam belajar, seperti yang tergambar pada pembelajaran di TPA yang menggunakan metode Iqro'. Oemar Hamalik menambahkan bahwa dalam konsep pembelajaran motivasi berarti seni mendorong siswa untuk terdorong melakukan kegiatan belajar sehingga tercapai tujuan belajar. ${ }^{10}$

Menurtu Sadirman Ciri-ciri siswa yang memiliki motivasi yang tinggi dikelas sebagaimana dikemukakan oleh Sadirman, yaitu: 1) Tekun dalam menghadapi tugas dan dapat belajar dalam waktu yang lama, 2) Ulet dalam menghadapi kesulitan dan tidak menyerah, juga tidak cepat puas atas prestasi yang dimiliki, 3) Menunjukan minat yang besar terhadap masalah belajar, 4) Lebih suka belajar dan tidak tergantung pada orang lain, 5) Dapat mempertahankan pendapatnya dan tidak mudah melepas apa yang dimiliki, 6) Senang mencari dan memecahkan masalah. ${ }^{11}$

${ }^{8}$ Muhammad Thobrani, dan Arif Mustofa, Belajar dan Pembelajaran; Pengembangan Wacana dan Praktik Pembelajaran dalam Pembangunan Nasional, (Jogjakarta: Ar-Ruzz Media, 2011), h. 33.

${ }^{9}$ Muhammad Thobrani dan Arif Mustofa, Belajar dan Pembelajaran; Pengembangan Wacana dan Praktik Pembelajaran dalam Pembangunan Nasional (Jogjakarta: Ar-Ruzz Media, 2011), h. 33.

${ }^{10}$ Oemar Hamalik, Kurikulum dan Pembelajaran (Jakarta: Bumi Aksara, 1999), h. 57.

${ }^{11}$ Sadirman, A.M, Interaksi dan Motivasi Belajar Siswa (Jakarta: Rajawali, 1986), h. 81 .

Jurnal Ilmiah Al QALAM, Vol. 12, No. 2, Juli-Desember 2018 
Ahmad Rifa'i dan Muhammad Nasir: Efektivitas Metode UMMI Terhadap Peningkatan Motivasi Belajar Membaca Alquran Siswa TPA Desa Pugaan Kecamatan Pugaan

Upaya untuk meningkatkan motivasi belajar dengan menerapkan motode belajar membaca Alquran seperti metode Ummi, metode ini mempunyai kelebihan dengan metode yang sudah dikembangkan dan tentunya berbeda dari metode sebelumnya, mutu guru terjaga dengan melalui proses tes/ tashih dan sertifikasi yang ketat, serta menggunakan 9 pilar sistem berbasis mutu yaitu 1) Goodwill manajemen, 2) Sertifikasi guru, 3) Tahapan baik dan benar, 4) Target jelas dan terukur, 5) Mastery learning yang konsisten, 6) Waktu memadai, 7) Quality Control yang Intensif, 8) Rasio guru dan siswa yang proporsional, 9) Progress report setiap siswa. ${ }^{12}$

Metode Ummi dengan mutu guru yang professional ditambah sistem berbasis mutu tentunya mampu meningkatkan motivasi belajar membaca Alquran sehingga bacaan Alquran generasi mudan menjadi lebih baik.

Berdasarkan latar belakang masalah dan gambaran umum yang telah dipaparkan di atas, peneliti memandang perlu untuk meneliti tentang "Evektivitas Metode Ummi terhadap Peningkatan Motivasi Belajar Membaca Alquran Siswa TPA Kecamatan Pugaan Kabupaten Tabalong”

Berdasarkan latar belakang masalah di atas, maka rumusan masalah dalam penelitian ini adalah bagaimana efektivitas metode Ummi dalam meningkatkan motivasi belajar membaca Alquran Siswa TPA Pugaan Kecamatan Pugaan?.

Berdasarkan rumusan masalah yang dikemukakan di atas penelitian ini bertujuan untuk mengetahui efektivitas metode Ummi dalam meningkatkan motivasi belajar membaca Alquran Siswa TPA Pugaan Kecamatan Pugaan.

Berikut hipotesis penelitan yang akan digunakan dalam penelitian ini adalah:

$\mathrm{H}_{0}$ : Tidak ada perbedaan motivasi belajar membaca Alquran yang signifikan antara penggunaan metode Ummi dengan metode Iqro’.

\footnotetext{
${ }^{12}$ Ummi Foundation, Modul Sertifikasi Guru Al-Qur'an Metode Ummi (Surabaya: Lembaga Ummi Foundation, 2011), h. 5.
}

Jurnal Ilmiah Al QALAM, Vol. 12, No. 2, Juli-Desember 2018 
Ahmad Rifa'i dan Muhammad Nasir: Efektivitas Metode UMMI Terhadap Peningkatan Motivasi Belajar Membaca Alquran Siswa TPA Desa Pugaan Kecamatan Pugaan

$\mathrm{H}_{1}$ : Ada perbedaan motivasi belajar membaca Alquran yang signifikan antara penggunaan metode Ummi dengan metode Iqro’

\section{B. Metode UMMI}

Metode ini muncul karena dilatar belakangi oleh semakin besarnya sekolah Islam terhadap pembelajaran Alquran. Khususnya bagi siswa SD dan MI. Adapun dasar dari metode Ummi adalah pendekatan dengan bahasa ibu. Bahasa ibu yang dimaksud adalah direct method yaitu metode langsung dan tidak banyak penjelasan, kedua ialah repetation atau diulang-ulang, yang ketiga yaitu kasih sayang yaitu kita dituntut harus bisa menunjukan kasih sayang kita terhadap anak didik kita. Demikian juga seorang guru yang mengajar Alquran jika ingin sukses hendaknya meneladani seorang ibu agar guru juga dapat menyentuh hati siswa mereka. ${ }^{13}$

\section{Latar Belakang Metode Ummi}

Adapun yang melatar belakangi dikembangkannya metode Ummi sebagai berikut:

a. Kebutuhan sekolah-sekolah Islam terhadap pembelajaran Alquran dirasa semakin lama semakin besar.

b. Pembelajaran membaca Alquran yang baik sangat membutuhkan sebuah sistem yang mampu menjamin mutu bahwa setiap anak usia lulus SD / MI harus bisa membaca Alquran secara tartil.

c. Banyaknya sekolah atau TPQ yang membutuhkan solusi bagi kelangsungan pembelajaran Alquran bagi siswa-siswinya.

d. Seperti halnya program pembelajaran yang lainnya bahwa dalam pembelajaran Alquran juga membutuhkan pengembangan, baik dari segi konten, konteks maupun support system-nya.

\footnotetext{
${ }^{13}$ Ummi Foundation, h. 4.
}

Jurnal Ilmiah Al QALAM, Vol. 12, No. 2, Juli-Desember 2018 
Ahmad Rifa'i dan Muhammad Nasir: Efektivitas Metode UMMI Terhadap Peningkatan Motivasi Belajar Membaca Alquran Siswa TPA Desa Pugaan Kecamatan Pugaan

\section{Visi, Misi dan Motto Metode Ummi}

Metode Ummi mempunyai misi "Menjadi lembaga terdepan dalam melahirkan generasi qur'ani”. Adapun misinya adalah sebagai berikut:

a. Mewujudkan lembaga profesional dalam pengajaran Alquran yang yang berbasis sosial dan dakwah.

b. Membangun sistem manajemen pengajaran Alquran yang berbasis pada mutu.

c. Mewujudkan pusat pengembangan pembelajaran Alquran.

Metode Ummi mengusung 3 motto yang menjadi keunggulannya yaitu: Mudah, Menyenangkan dan Menyentuh Hati. ${ }^{14}$

\section{Kekuatan Metode Ummi :}

Ummi tidak hanya mengandalkan kekuatan buku yang di pegang anak tapi lebih pada 3 kekuatan utama:

a. Metode

Metode (Buku Belajar Membaca Alquran Metode Ummi)Yang terdiri dari buku Pra TK, Jilid 1-6, Buku Ghorib, Tajwid Dasar dan Buku Ummi Edisi Dewasa

b. MutuGuru

MutuGuru :Semua guru melalui proses tes/ tashih dan sertifikasi yang ketat. Kualifikasi guru yang di harapkan adalah :tartil baca Alquran, menguasai ghoribul Quran dan tajwid, terbiasa baca Alquran tiap hari, mengusai metode Ummi, berjiwa murobbi, disiplin waktu, komitmen pada waktu

c. Sistem Berbasis mutu

Sistem Berbasis Mutu ada sembilan pilar bangunan sistem mutu yaitu: 1) Goodwill manajemen, 2) Sertifikasiguru, 3) Tahapan baik dan benar, 4) Target jelas dan terukur, 5) Masterylearning yang konsisten, 6)

\footnotetext{
${ }^{14}$ Ummi Foundation, h. 4.
}

Jurnal Ilmiah Al QALAM, Vol. 12, No. 2, Juli-Desember 2018 
Ahmad Rifa'i dan Muhammad Nasir: Efektivitas Metode UMMI Terhadap Peningkatan Motivasi Belajar Membaca Alquran Siswa TPA Desa Pugaan Kecamatan Pugaan

Waktumemadai, 7) Quality Control yang Intensif, 8) Rasio guru dan siswa yang proporsional, 9) Progress reportsetiap siswa. ${ }^{15}$

\section{Motivasi Belajar Membaca Alquran}

Motivasi berasal dari bahasa Inggris yaitu "motivation" yang mempunyai makna dorongan atau motivasi. Motivasi menurut istilah adalah keadaan dalam diri seseorang yang mendorong individu tersebut untuk melakukan aktivitas-aktivitas tertentu guna mencapai tujuan yang diinginkan. ${ }^{16}$ Sadirman menjelaskan bahwa motivasi dapat diartikan sebagai serangkaian usaha untuk menyediakan kondisi-kondisi tertentu, sehingga seseorang mau dan ingin melakukan sesuatu. ${ }^{17}$

Belajar menurut kamus Bahasa Indonesia berasal dari kata “ajar” yang artinya petunjuk yg diberikan kepada orang supaya diketahui (diturut), adapun belajar mempunyai arti berusaha mengetahui sesuatu; berusaha memperoleh ilmu pengetahuan (kepandaian, keterampilan). ${ }^{18}$ Sadirman menjelaskan bahwa belajar merupakan perubahan tingkah laku atau penampilan dengan serangkaian kegiatan seperti membaca, mengamati, mendengarkan, dan sebagainya. ${ }^{19}$

Objek kata kerja membaca pada sub judul ini adalah Alquran maka makna "membaca" adalah mengeja atau melafalkan apa yg tertulis, ${ }^{20}$. Berdasarkan penjelasan di atas maka motivasi belajar membaca Alquran adalah dorongan yang kuat untuk memperoleh pengetahuan tentang cara mengeja atau melapalkan Alquran.

Menurut Sadirman ciri-ciri motivasi belajar adalah sebagai berikut:

${ }^{15}$ Ummi Foundation, h. 5 .

${ }^{16}$ Eveline Siregar dan Hartini Nara, Teori Belajar dan Pembelajaran (Bogor: Galia Indonesia, 2014), h. 49.

${ }^{17}$ Sadirman, A.M, Interaksi dan Motivasi Belajar Mengajar (Jakarta: PT. Rajagrafindo, 2011), h. 75.

${ }^{18}$ Tim Penyusun Kamus Pusat Bahasa, Kamus Bahasa Indonesia (Jakarta: Pusat Bahasa, 2008), h. 24.

${ }^{19}$ Sadirman, A.M, Interaksi dan Motivasi Belajar Mengajar, h. 20.

${ }^{20}$ Tim Penyusun Kamus Pusat Bahasa, Kamus Bahasa Indonesia, h. 114.

Jurnal Ilmiah Al QALAM, Vol. 12, No. 2, Juli-Desember 2018 
Ahmad Rifa'i dan Muhammad Nasir: Efektivitas Metode UMMI Terhadap Peningkatan Motivasi Belajar Membaca Alquran Siswa TPA Desa Pugaan Kecamatan Pugaan

1. Tekun menghadapi tugas (dapat bekerja terus-menerus dalam waktu yang lama, tidak pernah berhenti sebelum selesai).

2. Ulet menghadapi kesulitan (tidak lekas putus asa) tidak memerlukan dorongan dari luar untuk berprestasi sebaik mungkin (tidak cepat puas dengan prestasi yang telah dicapainya).

3. Menunjukkan minat terhadap bermacam-macam masalah.

4. Lebih senang bekerja mandiri.

5. Cepat bosan pada tugas yang rutin (hal-hal yang bersifat mekanis, berulang-ulang begitu saja, sehingga kurang efektif.

6. Dapat mempertahankan pendapatnya (kalau sudah yakin akan sesuatu).

7. Tidak mudah melepaskan hal yang diyakini itu.

8. Senang mencari dan memecahkan masalah soal-soal. ${ }^{21}$

Sedikit berbeda dengan Sadirman, Hamzah B. Uno menyebutkan indikator motivasi belajar yang berbeda, dapat diklasifikasikan sebagai berikut:

1. Adanya hasrat dan keinginan berhasil.

2. Adanya dorongan dan kebutuhan dalam belajar.

3. Adanya harapan atau cita-cita masa depan.

4. Adanya penghargaan dalam belajar.

5. Adanya kegiatan yang menarik dalam belajar.

6. Adanya lingkungan belajar yang kondusif, sehingga memungkinkan seorang siswa dapat belajar dengan baik. ${ }^{22}$

\section{Metode Penelitian}

Penelitian ini menggunakan pendekatan kuantitatif dengan jenis penelitian eksperimen. Desain penelitian yang digunakan dalam penelitian ini adalah desain eksperimen semu (quasi eksperimen design).

${ }^{21}$ Sadirman, A.M, Interaksi dan Motivasi Belajar Mengajar, h. 83.

${ }^{22}$ Hamzah B. Uno, Teori Motivasi dan Pengukurannya: Analisis di Bidang Pendidikan (Jakarta: Bumi Aksara, 2011), h. 23. 
Ahmad Rifa'i dan Muhammad Nasir: Efektivitas Metode UMMI Terhadap Peningkatan Motivasi Belajar Membaca Alquran Siswa TPA Desa Pugaan Kecamatan Pugaan

Pada penelitian ini peneliti menggunakan sekelompok subyek penelitian dari suatu populasi tertentu, kemudian dikelompokan menjadi kelompok eksperimen dan kelompok kontrol. Pada kelompok eksperimen diberikan metode Ummi dan pada kelompok kontrol menggunakan metode Iqro'. Metode Ummi diterapkan di TPA Al Ihsan dan Metode Iqro' diterapkan di TPA Raudhatus Sa'adah. Selanjutnya pada kedua kelompok diberikan angket motivasi setelah pemberian perlakuan. Hasil angket motivasi dari kedua kelompok diuji secara statistik dengan menggunakan uji-t independen (Independent Sample t-Test).

Sesuai dengan desain penelitian yang akan digunakan, maka variabelvariabel yang digunakan dalam penelitian ini adalah sebagai berikut:

1. Variabel bebas (independent variable) adalah metode Ummi.

2. Variabel terikat (dependent variable adalah motivasi belajar membaca Alquran.

Populasi dalam penelitian ini adalah TPA Al Ihsan Desa Pugaan Kecamatan Pugaan, sedangkan sampel yang akan diteliti adalah siswa TPA Al Ihsan Desa Pugaan dan TPA Raudhatus Sa'adah yang masih Jilid 1 dan 2 buku Iqro’.

Data yang ingin diperoleh dari penelitian ini adalah Motivasi Belajar Membaca Alquran, maka teknik pengumpulan data yang digunakan dalam penelitian ini yaitu: Angket, dokumentasi, observasi.

Berikut ini kisi-kisi instrumen angket motivasi yang di pakai dalam penelitian:

Tabel 1. Kisi-Kisi Instrumen Motivasi Belajar Membaca Alquran

\begin{tabular}{|c|c|c|c|c|}
\hline \multirow{2}{*}{ No } & \multirow{2}{*}{ Indikator } & \multirow{2}{*}{ Diskriptor } & \multicolumn{2}{|c|}{ No Item Angket } \\
\hline & & & Positif & Negatif \\
\hline 1 & $\begin{array}{l}\text { Ketekunan dalam } \\
\text { Belajar }\end{array}$ & $\begin{array}{l}\text { 1. Kehadiran di tempat } \\
\text { belajar } \\
\text { 2. Mengikuti pembelajaran } \\
\text { di Kelas }\end{array}$ & $\begin{array}{l}1,3,4 \\
5,7\end{array}$ & $\begin{array}{l}2, \\
6,8\end{array}$ \\
\hline 2 & Ulet dalam & 3. Sikap terhadap kesulitan & 11,13 & $9,10,12$ \\
\hline
\end{tabular}

Jurnal Ilmiah Al QALAM, Vol. 12, No. 2, Juli-Desember 2018 
Ahmad Rifa'i dan Muhammad Nasir: Efektivitas Metode UMMI Terhadap Peningkatan Motivasi Belajar Membaca Alquran Siswa TPA Desa Pugaan Kecamatan Pugaan

\begin{tabular}{|l|l|l|l|l|}
\hline & $\begin{array}{l}\text { menghadapi } \\
\text { kesulitan }\end{array}$ & dan usaha mengatasinya. & & \\
\hline 3 & $\begin{array}{l}\text { Minat dan } \\
\text { ketajaman } \\
\text { perhatian dalam } \\
\text { belajar }\end{array}$ & $\begin{array}{l}\text { 4. } \begin{array}{l}\text { Kebiasaan dalam } \\
\text { mengikuti pelajaran di } \\
\text { TPA }\end{array} \\
\text { 5. Semangat dalam } \\
\text { mengikuti pelajaran }\end{array}$ & 14,19 & 18,16 \\
\hline 4 & $\begin{array}{l}\text { Berprestasi dalam } \\
\text { belajar }\end{array}$ & $\begin{array}{l}\text { 6. Keinginan untuk } \\
\text { berprestasi dan hasil } \\
\text { belajar. }\end{array}$ & $20,21,22$ \\
\hline 5 & $\begin{array}{l}\text { Mandiri dalam } \\
\text { belajar }\end{array}$ & $\begin{array}{l}\text { Penyelesaian tugas } \\
\text { belajar dan menggunakan } \\
\text { kesempatan diluar jam } \\
\text { pelajaran di TPA }\end{array}$ & 23 & 24 \\
\hline
\end{tabular}

Instumen angket motivasi menggunakan skala yang menyediakan empat alternatif jawaban, yaitu: Sangat Setuju (SS), Setuju (S), Tidak Setuju (TS), Sangat Tidak Setuju (STS), skor pernyataan positif berbeda dengan skor pernyataan negatif. Berikut ini pedoman pemberian skor pernyataan positif dan negarif:

Tabel 2. Pedoman Penskoran Angket Pernyataan Positif Dan Negarif

\begin{tabular}{|c|c|c|c|c|}
\hline \multirow{2}{*}{ Pernyataan } & \multicolumn{4}{|c|}{ Skor Angket } \\
\cline { 2 - 5 } & SS & S & TS & TST \\
\hline Positif (+) & 4 & 3 & 2 & 1 \\
\hline Negatif (-) & 1 & 2 & 3 & 4 \\
\hline
\end{tabular}

Berikut ini pedoman penskoran instrument angket dengan skala 4 dan 24 pernyataan.

Tabel 3. Pedoman Penskoran Instrumen Angket Motivasi

\begin{tabular}{|c|c|c|c|c|}
\hline $\begin{array}{c}\text { Jenis } \\
\text { Instrumen }\end{array}$ & $\begin{array}{c}\text { Bobot } \\
\text { Soal }\end{array}$ & $\begin{array}{c}\text { Jumlah } \\
\text { Soal }\end{array}$ & $\begin{array}{c}\text { Skor } \\
\text { Maksimal }\end{array}$ & $\begin{array}{c}\text { Skor } \\
\text { Minimal }\end{array}$ \\
\hline Angket & 4 & 24 & 96 & 25 \\
\hline
\end{tabular}


Ahmad Rifa'i dan Muhammad Nasir: Efektivitas Metode UMMI Terhadap Peningkatan Motivasi Belajar Membaca Alquran Siswa TPA Desa Pugaan Kecamatan Pugaan

Menentukan kategori tingkat motivasi siswa dapat dilakukan berdasarkan skor perolehan dibagi skor maksimal kemudian dikali 100, seperti rumus dibawah ini:

$$
\text { Nilai akhir }=\frac{\text { skor perolehan }}{\text { skor maksimal }} \times 100
$$

Skor yang diperoleh dari angket motivasi kemudian diinterpretasi menjadi nilai motivasi siswa dengan menggunakan kategori yang diadaptasi dari Zainal Arifin sebagai berikut: ${ }^{23}$

\section{Tabel 4. Interpretasi Hasil Angket Motivasi}

\begin{tabular}{|c|c|}
\hline Nilai & Kualifikasi Motivasi \\
\hline $85-100$ & Sangat Tinggi \\
\hline $70-84$ & Tinggi \\
\hline $55-69$ & Cukup \\
\hline $40-54$ & Rendah \\
\hline $25-39$ & Sangat Rendah \\
\hline
\end{tabular}

Analisis data akan menampilkan data motivasi kelas eksperimen dan motivasi kelas kontrol, kemudian dilakukan pengujian hipotesis, dengan menggunakan diuji statistik Independent Sample t-Testmemakai bantuan softwareSPSSversion 22 for windows dengan taraf signifikan yang diterapkan yaitu kesalahan $5 \%$.

Penggunaan Independent Sample t-Test harus memenuhi persyaratan distribusi normal maka dilakukan uji normalitas (uji Shapiro-Wilk) dan variansi antar kelompok homogen maka dilakukan uji homogenitas (uji F (Levene's Test for Equality of Variances)dengan taraf signifikan yang diterapkan yaitu kesalahan $5 \%$.

${ }^{23}$ Zainal Arifin, Evaluasi Pembelajaran, Prinsip-Teknik-Prosedur (Bandung: PT Remaja Rosdakarya, 2012), h. 45. 
Ahmad Rifa'i dan Muhammad Nasir: Efektivitas Metode UMMI Terhadap Peningkatan Motivasi Belajar Membaca Alquran Siswa TPA Desa Pugaan Kecamatan Pugaan

\section{E. Hasil Penelitian}

\section{Deskripsi Data}

Penelitian ini menggunakan desain eksperimen dengan menggunakan metode Ummi untuk mengetahui peningkatan Motivasi Belajar Membaca Alquran di TPA Al Ihsan dan TPA Raudhatus Sa'adah desa Pugaan Kecamatan Pugaan Kabupaten Tabalong tahun 2018. Subyek penelitian ini terdiri dari dua kelas yaitu kelas ekperimen di TPA Al Ihsan diberi perlakuan dengan menerapkan metode Ummi dan kelas kontrol di TPA Raudhatus Sa'adah dilakukan proses pembelajaran seperti biasa yaitu menggunakan metode Iqro' . Kelas eksperimen berjumlah 19 siswa dan kelas kontrol berjumlah 21 siswa.

Penerapan metode Ummi di TPA Al Ihsan dilakukan pada hari rabu tanggal 21 Maret 2018 dimulai pada pukul 14.00 - 15.00 WITA, adapun metode ummi melakukan proses belajar seperti biasa. Setelah diberi perlakuan kedua kelas diberikan angket untuk mengukur movitasi belajar Alquran siswa TPA tersebut. Motivasi Belajar Membaca Alquran diukur dengan instrumen angket berjumlah 24 pernyataan.

Berikut ini distribusi motivasi belajar membaca Alquran di TPA Al Ihsan pada kelas eksperimen dan di TPA Raudhatus Sa'adah pada kelas kontrol adalah sebagai berikut:

Tabel 5. Distribusi Frekuensi Motivasi Belajar Membaca Alquran Masalah Kelas Eksperimen dan Kelas Kontrol

\begin{tabular}{|c|c|c|c|c|c|}
\hline \multirow{2}{*}{ Nilai } & \multirow{2}{*}{ Kualifikasi Motivasi } & \multicolumn{4}{|c|}{ Kelas } \\
\cline { 3 - 5 } & & $\mathbf{f}$ & \% & $\mathbf{f}$ & \% \\
\hline $85-100$ & Sangat Tinggi & 10 & 52.63 & 3 & 14.29 \\
\hline $70-84$ & Tinggi & 8 & 42.11 & 15 & 71.42 \\
\hline $55-69$ & Cukup & 1 & 5.26 & 3 & 14.29 \\
\hline $40-54$ & Rendah & 0 & 0 & 0 & 0 \\
\hline $25-39$ & Sangat Rendah & 0 & 0 & 0 & 0 \\
\hline & Total & 19 & 100 & 21 & 100 \\
\hline
\end{tabular}


Ahmad Rifa'i dan Muhammad Nasir: Efektivitas Metode UMMI Terhadap Peningkatan Motivasi Belajar Membaca Alquran Siswa TPA Desa Pugaan Kecamatan Pugaan

Untuk mempermudah memahami tabel di atas maka secara visual dapat dilihat pada grafik distribusi frekuensi motivasi belajar membaca Alquran di TPA Al Ihsan pada kelas eksperimen dan di TPA Raudhatus Sa'adah pada kelas kontrol pada grafik berikut ini:

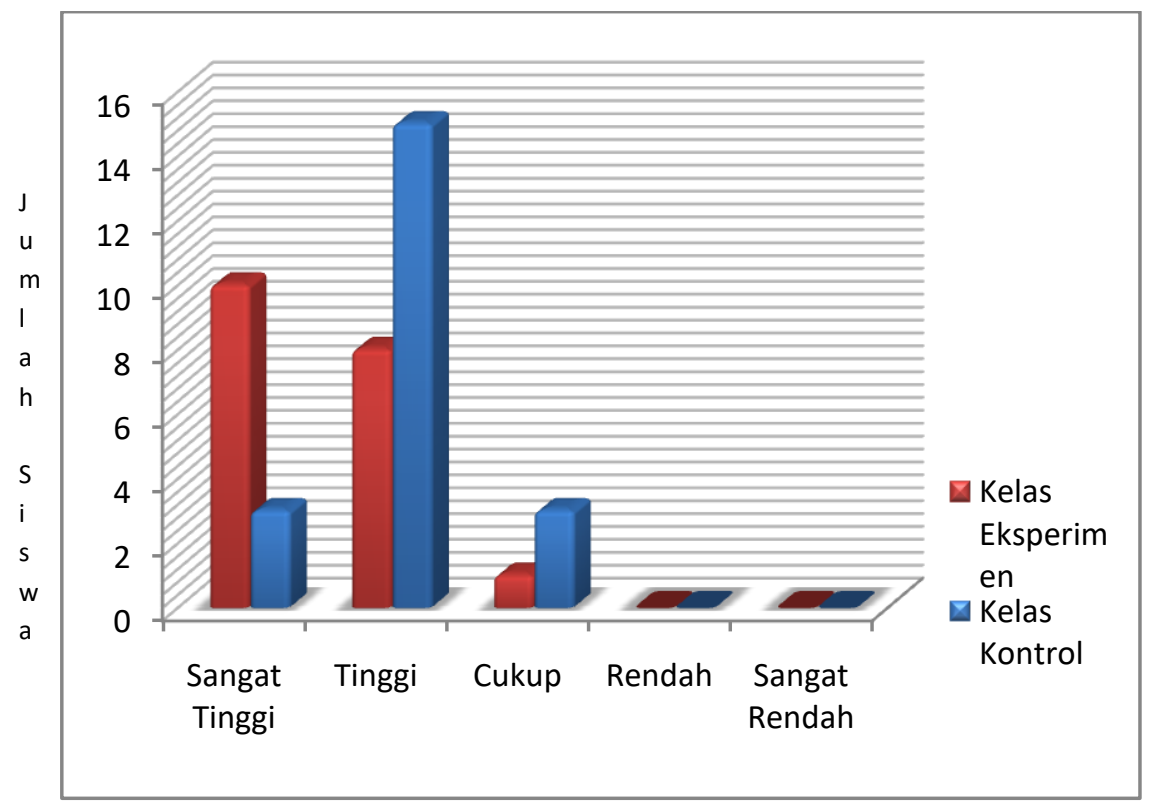

Gambar 1. Histogram Frekuensi Motivasi Belajar Membaca Alquran di TPA Al Ihsan pada kelas eksperimen dan di TPA Raudhatus Sa'adah pada kelas kontrol

Dari gambar di atas sangat jelas bahwa pada kelas eksperimen (TPA Al Ihsan) mayoritas Motivasi Belajar Membaca Alquran siswa sangat tinggi dengan menggunakan metode Ummi yaitu sebanyak 10 (52,63\%) siswa dari 19 total siswa di kelas eksperimen, pada gambar 4.1 sangat jelas balok pada kategori "sangat tinggi" lebih tinggi dibandingkan balok pada kategori yang lain, sedangkan pada kelas kontrol (TPA Raudhatus Sa'adah) mayoritas Motivasi Belajar Membaca Alquran siswa berada pada kategori tinggi yaitu sebanyak $15(71,42 \%)$ siswa dari total siswa 21 orang, dapat dilihat dengan jelas pada gambar 1 . 
Ahmad Rifa'i dan Muhammad Nasir: Efektivitas Metode UMMI Terhadap Peningkatan Motivasi Belajar Membaca Alquran Siswa TPA Desa Pugaan Kecamatan Pugaan

\section{Analisis Data}

Sebelum menganalisis data menggunakan independent sample t-test, data harus memenuhi syarat. Data yang akan di uji harus berdistribusi normal dan berasal dari varian yang sama, oleh karena itu dilakukan terlebih dahulu uji normalitas dan uji homogenitas.

Uji Shapiro-Wilk digunakan untuk mengetahui normalitas data Motivasi Belajar Membaca Alquran di TPA Al Ihsan dan TPA Raudhatus Sa'adah. Dasar Pengambilan Keputusan dalam Uji Normalitas Shapiro-Wilk adalah sebagai berikut:

1. Jika nilai sig. >0,05, maka data berdistribusi normal

2. Jika nilai sig. $<0,05$, maka data tidak berdistribusi normal

Adapun data hasil uji normalitas data Motivasi Belajar Membaca Alquran di TPA Al Ihsan dan TPA Raudhatus Sa'adah adalah sebagai berikut:

Tabel 6. Uji Normalitas Data Motivasi Belajar Membaca Alquran Kelas Eksperimen dan Kelas Kontrol

\begin{tabular}{|ll|r|r|r|}
\hline \multirow{2}{*}{ Kelas } & \multicolumn{3}{|c|}{ Shapiro-Wilk } \\
\cline { 3 - 5 } & & Statistic & \multicolumn{1}{c|}{ Df } & \multicolumn{1}{c|}{ Sig. } \\
\hline \multirow{2}{*}{ Nilai } & Kelas Ekspremen & .927 & 19 & .151 \\
& Kelas Kontrol & .926 & 21 & .117 \\
\hline
\end{tabular}

Berdasarkan tabel 4.15 menunjukkan bahwa hasil uji normalitas dengan menggunakan uji Shapiro-Wilk pada tabel di atas menunjukkan bahwa nilai signifikansi data Motivasi Belajar Membaca Alquran kelas eksperimenadalah 0,151 dan data Motivasi Belajar Membaca Alquran kelas kontrol adalah 0,117. Kedua nilai signifikansi tersebut lebih besar dari 0,05, maka dapat disimpulkan bahwa data data Motivasi Belajar Membaca Alquran kelas eksperimendan kelas kontrol berdistribusi normal dan sudah memenuhi prasyarat untuk melakukan uji selanjutnya. Adapun rincian lengkap output uji normalitas menggunakan SPSS Version 22 for Windows terdapat di lampiran. 
Ahmad Rifa'i dan Muhammad Nasir: Efektivitas Metode UMMI Terhadap Peningkatan Motivasi Belajar Membaca Alquran Siswa TPA Desa Pugaan Kecamatan Pugaan

Uji prasyarat yang kedua untuk melakukan analisis independent sampel T Tes adalah uji homogenitas yang bertujuan untuk mengetahui apakah data berasal dari varian yang sama atau tidak. Uji homogenitas menggunakan uji Levene dengan bantuan program SPSS Version 22 for Windows dengan dasar Pengambilan Keputusan dalam Uji homogenitas sebagai berikut:

- Nilai signifikansi (p) > 0.05 menunjukkan kelompok data berasal dari populasi yang memiliki varians yang sama (homogen)

- Nilai signifikansi (p) < 0.05 menunjukkan masing-masing kelompok data berasal dari populasi dengan varians yang berbeda (tidak homogen)

Adapun data hasil uji homogenitas data Motivasi Belajar Membaca Alquran di TPA Al Ihsan dan TPA Raudhatus Sa'adah adalah sebagai berikut:

\section{Tabel 7. Uji Homogenitas Data Motivasi Belajar Membaca Alquran Kelas Eksperimen dan Kelas Kontrol}

Nilai

\begin{tabular}{|c|c|c|c|}
\hline Levene Statistic & df1 & df2 & Sig. \\
\hline 1.041 & 1 & 38 & .314 \\
\hline
\end{tabular}

Berdasarkan tabel 4.2 menunjukkan bahwauji homogenitas dengan menggunakan uji Levene Statistic nilai signifikansi data Motivasi Belajar Membaca Alquran kelas kontrol dan kelas eksperimen adalah 0,314. Nilai ini lebih besar dari 0,05, maka data tersebut homogen. Adapun rincian output yang lengkap uji homogenitas data di atas terdapat pada lampiran.

Pengujian hipotesis merupakan langkah untuk menentukan apakah hipotesis diterima atau ditolak. Data yang digunakan adalah data Motivasi Belajar Membaca Alquran kelas eksperimen dan kontrol. Hipotesis yang akan diujikan pada bagian ini adalah: 
Ahmad Rifa'i dan Muhammad Nasir: Efektivitas Metode UMMI Terhadap Peningkatan Motivasi Belajar Membaca Alquran Siswa TPA Desa Pugaan Kecamatan Pugaan

$\mathrm{H}_{0} \quad$ : Tidak ada perbedaan motivasi belajar membaca Alquran yang signifikan antara penggunaan metode Ummi dengan metode Iqro'.

$\mathrm{H}_{1}$ : Ada perbedaan motivasi belajar membaca Alquran yang signifikan antara penggunaan metode Ummi dengan metode Iqro'

Dasar pengambilan keputusan hipotesis di atas dilihat dari nilai signifikansi sebagai berikut:

- Apabila nilai probabilitas $(\mathrm{p})>0,05$ maka $\mathrm{H}_{0}$ diterima.

- Apabila nilai probabilitas $(\mathrm{p})<0,05$ maka $\mathrm{H}_{0}$ ditolak.

Pengujian hepotesis tersebut dilakukan dengan independent sample $t$ test, dengan menguji perbedaan data Motivasi Belajar Membaca Alqurankelas eksperimen yang menggunakan metode Ummi dengan data Motivasi Belajar Membaca Alqurankelas kontrol yang menggunakan metode Iqro’.

Data yang digunakan pada tahap ini adalah data Motivasi Belajar Membaca Alqurankelas eksperimen dan kontrol. Berikut rangkuman hasil analisis independent sample t-test dengan menggunakan bantuan SPSS version 22 for windows untuk mengukur perbedaan data Motivasi Belajar Membaca Alqurandi kelas eksperimen dengan kelas kontrol yang diukur dari hasil angket motivasi setelah diberikan perlakuan:

Tabel 8. Rangkuman Hasil Analisis Independent Sample T-Test Antar Kelompok Data Motivasi Belajar Membaca Alquran

\begin{tabular}{|l|r|r|r|r|r|}
\hline \multirow{2}{*}{$\begin{array}{c}\text { Sumber } \\
\text { Data }\end{array}$} & \multicolumn{2}{|c|}{ Mean \pm Standar Deviasi } & \multirow{2}{*}{$\mathrm{t}_{\text {hitung }}$} & $\mathrm{P}$ & Keterangan \\
\cline { 2 - 3 } & Eksperimen & \multicolumn{1}{|c|}{ Kontrol } & & \\
\hline $\begin{array}{l}\text { Angket } \\
\text { Motivasi }\end{array}$ & $83,44 \pm 6,82$ & $\begin{array}{r}77,18 \pm \\
6,00\end{array}$ & 3,089 & 0,004 & Signifikan \\
\hline
\end{tabular}

Dari tabel diatas, bisa dilihat nilai probabilitas pada uji beda hasil angket Motivasi Belajar Membaca Alqurankelas eksperimen dan kontrol adalah 0,004, nilai tersebut kurang dari 0,05 maka $\mathrm{H}_{0}$ ditolak maka $\mathrm{H}_{1}$ diterima. 
Ahmad Rifa'i dan Muhammad Nasir: Efektivitas Metode UMMI Terhadap Peningkatan Motivasi Belajar Membaca Alquran Siswa TPA Desa Pugaan Kecamatan Pugaan

Dengan demikian dapat diketahui bahwa ada perbedaan motivasi belajar membaca Alquran yang signifikan antara penggunaan metode Ummi dengan metode Iqro.

\section{Pembahasan Motivasi Belajar Membaca Alquran}

Tingginya motivasi belajar membaca Alquran menjadi salah satu faktor keberhasilan pembelajaran baca tulis Alquran di TPA atau di lembaga Islam lainnya, oleh karena itu motivasi menjadi faktor penting yang harus diperhatikan oleh seorang pendidik. Metode Ummi mampu meningkatkan motivasi belajar siswa dengan konsep bahasa ibu yang mengusung 3 motto yaitu mudah, menyenangkan dan menyentuh hati. ${ }^{24}$

Konsep bahasa ibu menjadi hal yang sangat disenangi oleh siswa karena siswa merasa belajar dengan penuh kasih sayang, hal ini sesuai dengan salah satu mottonya yaitu menyentuh hati. Konsep bahasa ibu menjadikan belajar membaca Alquran menjadi lebih mudah, dibarengi dengan metode mengajar yang menyenangkan seperti menggunakan nada dan nyanyian untuk ketika menerapkan metode ini.

Selain keunggunalan metode Ummi di atas, ada keunggulan lain yang menjadikan metode ini menjadi alternatif dalam mengajarkan Alquran yaitu adanya syarat agar yang mengajarkan metode ini harus mempunyai sertifikasi guru (lisensi) untuk menjamin mutu pada setiap guru yang akan menggunakan

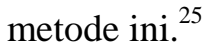

Dengan keunggunal metode Ummi tersebut ditambah dengan guru profesional (sertifikasi guru) tentu dapat meningkatkan motivasi belajar membaca Alquran dan menjadikan generasi qurani yang unggul. Data yang memperkuat argumen tersebut diambil dari data distribusi motivasi belajar membaca Alquran yang menjelaskan bahwa pada kelas eksperimen (TPA Al Ihsan) yang menerapkan metode Ummi mayoritas Motivasi Belajar Membaca Alquran siswa sangat tinggi dengan menggunakan metode Ummi yaitu

\footnotetext{
${ }^{24}$ Ummi Foundation, Modul Sertifikasi Guru Al-Qur'an Metode Ummi, h. 4.

${ }^{25}$ Ummi Foundation, h. 5.
} 
Ahmad Rifa'i dan Muhammad Nasir: Efektivitas Metode UMMI Terhadap Peningkatan Motivasi Belajar Membaca Alquran Siswa TPA Desa Pugaan Kecamatan Pugaan

sebanyak $10(52,63 \%)$ siswa dari 19 total siswa di kelas eksperimen, sedangkan pada kelas kontrol (TPA Raudhatus Sa'adah) yang menerapkan metode Iqro' mayoritas Motivasi Belajar Membaca Alquran siswa berada pada kategori tinggi yaitu sebanyak $15(71,42 \%)$ siswa dari total siswa 21 orang.

Untuk memastikan bahwa metode Ummi efektif dibandikan dengan metode Iqro' maka dilakukan uji beda dengan nilai probabilitas pada uji beda hasil angket Motivasi Belajar Membaca Alqurankelas eksperimen dan kontrol adalah 0,004, nilai tersebut kurang dari 0,05 maka $\mathrm{H}_{0}$ ditolak maka $\mathrm{H}_{1}$ diterima, artinya ada perbedaan yang signifikan antara kelas eksperimen yang menggunakan metode Ummi dengan kelas kontrol yang menggunakan metode Iqro'. Dengan demikian dapat disimpulkan bahwa ada metode Ummi efektif meningkatkan motivasi belajar membaca Alquran.

\section{F. Simpulan}

Berdasarkan hasil analisis data dan pembahasan yang telah dilakukan, maka diperoleh kesimpulan bahwa metode Ummi efektif dalam meningkatkan motivasi belajar membaca Alquran Siswa TPA Desa Pugaan Kecamatan Pugaan. Motivasi belajar membaca Alquran siswa TPA Al Ihsan mayoritas berada pada kategori sangat tinggi setelah diterapkan metode Ummi yaitu sebanyak $10(52,63 \%)$ siswa dari 19 total siswa. Pada hasil uji-t menggunakan independent sample t-test dengan membedakan data hasil angket motivasi belajar membaca Alquran diperoleh nilai signifikansi 0,004, nilai tersebut kurang dari 0,05 maka $\mathrm{H}_{0}$ ditolak maka $\mathrm{H}_{1}$ diterima, artinya ada perbedaan yang signifikan antara kelas eksperimen yang menggunakan metode Ummi dengan kelas kontrol yang menggunakan metode Iqro'. Dengan demikian dapat disimpulkan bahwa ada metode Ummi efektif meningkatkan motivasi belajar membaca Alquran. 
Ahmad Rifa'i dan Muhammad Nasir: Efektivitas Metode UMMI Terhadap Peningkatan Motivasi Belajar Membaca Alquran Siswa TPA Desa Pugaan Kecamatan Pugaan

\section{Daftar Pustaka}

Arifin, Zainal. Evaluasi Pembelajaran, Prinsip-Teknik-Prosedur. Bandung: PT Remaja Rosdakarya, 2012.

ArikuntO, Suharsimi. Prosedur Penelitian Suatu Pendekatan Praktik Edisi Revisi VI. Jakarta: Rineka Cipta, 2006.

Ash Shiddieqy, M. Hasbi. Sejarah dan Pengantar Ilmu Al-Qur'an dan Tafsir. Semarang: Pustaka Riski Putra, 1997.

B. Uno, Hamzah. Teori Motivasi dan Pengukurannya: Analisis di Bidang Pendidikan. Jakarta: Bumi Aksara, 2011.

Budiyanto, HM. Prinsip-prinsip Buku Iqro’. Yogyakarta: Team tadarus AMM, t.t.

Hamalik, Oemar. Kurikulum dan Pembelajaran. Jakarta: Bumi Aksara, 1999.

Hasan, Iqbal. Pokok-Pokok Materi Metodologi Penelitian dan Aplikasinya. Jakarta: Ghalia Indonesia, 2002.

Mufron, Ali. Ilmu Pendidikan Islam. Yogyakarta: Aura Pustaka, 2013.

Noer Aly, Hery. Ilmu Pendidikan Islam. Jakarta: Logos, 1999.

Sadirman, A.M. Interaksi dan Motivasi Belajar Mengajar. Jakarta: PT. Rajagrafindo, 2011.

_. Interaksi dan Motivasi Belajar Siswa. Jakarta: Rajawali, 1986.

Siregar, Eveline, dan Hartini Nara. Teori Belajar dan Pembelajaran. Bogor: Galia Indonesia, 2014.

Sugiono. Metode Penelitian Pendidikan Pendekatan Kuantitatif, Kualitatif, dan $R \& D, C e t . X V$. Bandung: Alfabeta, 2013.

Thobrani, Muhammad, dan Arif Mustofa. Belajar dan Pembelajaran; Pengembangan Wacana dan Praktik Pembelajaran dalam Pembangunan Nasional. Jogjakarta: Ar-Ruzz Media, 2011.

Tim Penyusun Kamus Pusat Bahasa. Kamus Bahasa Indonesia. Jakarta: Pusat Bahasa, 2008.

Ummi Foundation. Modul Sertifikasi Guru Al-Qur'an Metode Ummi. Surabaya: Lembaga Ummi Foundation, 2011. 
Ahmad Rifa'i dan Muhammad Nasir: Efektivitas Metode UMMI Terhadap Peningkatan Motivasi Belajar Membaca Alquran Siswa TPA Desa Pugaan Kecamatan Pugaan

Yunus, Mahmud. Metodik Khusus Pendidikan Agama. Cet. Ke-12. Jakarta: Hida Karya Agung, 1990.

Jurnal Ilmiah Al QALAM, Vol. 12, No. 2, Juli-Desember 2018 
Ahmad Rifa'i dan Muhammad Nasir: Efektivitas Metode UMMI Terhadap Peningkatan Motivasi Belajar Membaca Alquran Siswa TPA Desa Pugaan Kecamatan Pugaan

Jurnal Ilmiah Al QALAM, Vol. 12, No. 2, Juli-Desember 2018 